Kaganga : Jurnal Pendidikan Sejarah dan Riset Sosial Humaniora

Volume 2, Nomor 2, Desember 2019

e-ISSN : 2598-4934

p-ISSN : 2621-119X

DOI : https://doi.org/10.31539/kaganga.v2i2.890

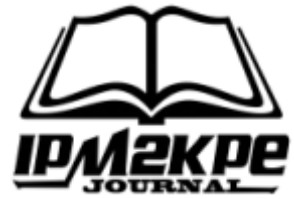

\title{
MENGATASI PROBLEMATIKA BELAJAR SEJARAH SISWA MENGGUNAKAN METODE THINK PAIR SHARE
}

\author{
Nahdatul Hazmi \\ STKIP Abdi Pendidikan Payakumbuh \\ hazminahdatul@gmail.com
}

\begin{abstract}
ABSTRAK
Penelitian ini bertujuan untuk mengetahui pengaruh positif penerapan model think pair share terhadap hasil belajar siswa dalam pembelajaran sejarah di kelas X SMAN 1 Lareh Sago Halaban. Mengumpulkan data menggunakan tehnik quasi eksperimen dan juga dengan deskriptif, dimana selain angka-angka yang diperoleh juga dari hasil observasi dan diperkuat dengan wawancara. Hasil penelitian, dari analisa didapat $\mathrm{t}$ hitung $=18,43$ dan $\mathrm{t}$-tabel $=1,73$ dimana $1,73<18,43>1,73$ yang berarti hipotesis diterima pada taraf kepercayaan $95 \%(\alpha=0,05)$. Dengan demikian dapat disimpulkan bahwa, terdapat pengaruh positif model dari pembelajaran kooperatif tipe think pair share terhadap hasil belajar siswa dalam pembelajaran sejarah di X SMAN 1 Lareh Sago Halaban.
\end{abstract}

Kata Kunci : Problematika, Model Pembelajaran, Think Pair Share, Hasil Belajar

\begin{abstract}
This study aims to determine the positive effect of the application of the think pair share model on student learning outcomes in history learning in class X SMAN 1 Lareh Sago Halaban.This paper in collecting data using quasi-experimental techniques and also with descriptive, where in addition to the figures obtained also from observations and strengthened by interviews. From the analysis obtained $t$ count $=18.43$ and t-table $=1.73$ where $1.73<18.43>1.73$ which means the hypothesis is accepted at the 95\% confidence level $(\alpha=0.05)$. Thus it can be concluded that, there is a positive effect of the model of cooperative learning in the type of think pair share on student learning outcomes in history learning at X SMAN 1 Lareh Sago Halaban.
\end{abstract}

Keywords: Problems, Think Pair Share Learning Models, Learning Outcomes

\section{PENDAHULUAN}

Proses pembelajaran merupakan salah satu komponen dalam pendidikan. Setiap sekolah tidak terlepas dari proses pembelajaran, baik tingkat sekolah dasar, sekolah menengah pertama, sekolah menengah atas, ataupun perkuliahan. Proses pembelajaran merupakan salah satu bagian dari pendidikan, pendidikan merupakan hal penting dan telah menjadi kebutuhan setiap manusia. Menurut Undang-Undang Republik Indonesia No. 20 tahun 2003 dalam ketentuan umum Bab I Pasal 1 Butir 1 tentang 
Sistem Pendidikan Nasional: "Pendidikan adalah usaha sadar dan terencana untuk mewujudkan suasana belajar dan proses pembelajaran agar peserta didik secara aktif mengembangkan potensi dirinya untuk memiliki kekuatan spiritual keagamaan, pengendalian diri, kepribadian, kecerdasan, akhlak mulia, serta keterampilan yang diperlukan dirinya, masyarakat, bangsa dan negara. Untuk mengembangkan potensi yang ada didalam diri manusia maka tidak lepas dari dunia pendidikan".

Proses pembelajaran yang efektif merupakan salah satu tujuan pendidikan nasional. Proses pembelajaran di kelas terdapat berbagai masalah. Baik masalah guru (sebagai pendidik) dan siswa (sebagai peserta didik). Karakteristik individu yang berbeda-beda membutuhkan pendidik yang berkualitas agar mampu memahami karakteristik individu tersebut.

Dalam keseluruhan proses pendidikan di sekolah, proses pembelajaran merupakan kegiatan yang paling pokok, karena berhasil atau tidaknya proses pendidikan di sekolah tergantung bagaimana proses pembelajaran yang di tentukan. Keberhasilan proses pembelajaran di sekolah dapat tercermin dari hasil belajar yang dicapai siswa setelah mengikuti kegiatan pembelajaran. Dalam pelaksanaan kegiatan pembelajaran di kelas biasanya guru berusaha untuk merencanakan apa yang akan di lakukan dan memahami materi apa yang akan di ajarkan kepada siswanya. Namun tidak semua yang diterangkan oleh guru akan dimengerti oleh siswa.
Mata pelajaran Sejarah merupakan mata pelajaran yang sangat penting untuk dipelajari. Dengan mempelajari sejarah siswa mampu mempelajari kejadian yang terjadi pada masa lampau, baik itu dengan membaca dan memahami maupun berhadapan langsung dengan tempat,tokoh maupun bukti sejarah yang ada. Problemtika pembelajaran sejarah ini sebenarnya sangat banyak namun disini akan dilihat dari proses tranfer pengetahuan yang terjadi dalam kelas berupa metode ataupun model pembelajaran yang dicoba menerapkannya dalam proses pembelajaran. Dengan menerapkan model atau metode think pair share dalam pembelajaran diharapkan beberapa problematika seperti kurangnya minat belajar siswa, motivasi belajar yang rendah, belajar yang membosankan, sering keluar masuk kelas saat pembelajaran berlangsung, serta rendahnya hasil belajar siswa itu sendiri. Problematika yang dimaksud disini adalah masalah-masalah yang dihadapi oleh guru dan siswa dalam proses pembalajaran sejarah, seperti yang dibawah ini; 1) rendahnya aktivitas belajar siswa, 2) rendahnya hasil belajar siswa, 3) nilai ulangan harian siswa rendah, 4) pembelajaran di kelas masih membosankan dan monoton, 5) guru belum melakukan variasi pembelajaran, 6) siswa pasif selama proses pembelajaran, 7) kurangnya penggunaan media pembelajaran, 8) siswa sering keluar masuk, 9) guru belum pernah menerapkan model ThinkPair Share.

Model pembelajaran kooperatif adalah rangkaian kegiatan belajar yang dilakukan oleh siswa dalam 
kelompok-kelompok tertentu untuk mencapai tujuan pembelajaran yang telah dirumuskan.

$$
\text { Suprijono }
$$

mengemukakan bahwa pembelajaran kooperatif adalah konsep yang lebih luas meliputi semua jenis kerja kelompok termasuk bentuk-bentuk yang lebih dipimpin oleh guru atau diarahkan oleh guru. Secara umum pembelajaran kooperatif lebih diarahkan oleh guru, dimana guru menetapkan tugas dan pertanyaanpertanyaan serta menyediakan bahan-bahan dan informasi yang dirancang untuk membantu siswa menyelesaikan masalah yang dimaksudkan.

Pembelajaran kooperatif adalah model pembelajaran yang berfokus pada penggunaan kelompok kecil siswa untuk bekerja sama dalam memaksimalkan kondisi belajar untuk mencapai tujuan belajar.

Dari beberapa definisi yang dikemukakan oleh para ahli di atas, maka dapat ditarik kesimpulan bahwa pembelajaran kooperatif adalah model pembelajaran yang menempatkan siswa dalam kelompok-kelompok kecil yang anggotanya bersifat heterogen, terdiri dari siswa yang berprestasi tinggi, sedang dan rendah, perempuan dan laki-laki dengan latar belakang etnik yang berbeda untuk saling membantu dan bekerja sama mempelajari materi pelajaran agar belajar semua anggota maksimal.

Think Pair Share merupakan salah satu tipe pembelajaran kooperatif yang dikembangkan oleh Frank Lyman, dari universitas Maryland pada tahun 1985 sebagai salah satu untuk kegiatan cooperative learning. Think Pair Share memberikan waktu kepada para siswa untuk berfikir dan merespon serta saling bantu sama lain. Think Pair Share memberi siswa kesempatan untuk bekerja sendiri serta bekerja sama dengan orang lain. TPS(Think Pair Share) atau (Berfikir-Berpasangan-Berbagi) merupakan jenis pembelajaran kooperatif yang dirancang untuk mempengaruhi pola interaksi siswa. TPS menghendaki siswa bekerja saling membantu dalam kelompok kecil (2-6 anggota) dan lebih dirincikan oleh penghargaan kooperatif, dari pada penghargaan individual (Ibrahim, 2000).

Penerapan model pembelajaran Think Pair Share diharapkan siswa dapat mengembangkan keterampilan berfikir dan menjawab dalam komunikasi antara satu dengan yang lain, serta bekerja saling membantu dalam kelompok kecil. Hal ini sesuai dengan pengertian dari model pembelajaran Think Pair Share itu sendiri, Think Pair Share adalah pembelajaran yang memberi siswa kesempatan untuk bekerja sendiri dan bekerjasama dengan orang lain. Dalam hal ini, guru sangat berperan penting untuk membimbing siswa melakukan diskusi, sehingga terciptanya suasana belajar yang lebih hidup, aktif, kreatif, efektif dan menyenangkan.

Model pembelajaran Think Pair Share siswa secara langsung dapat memecahkan masalah, memahami suatu materi secara berkelompok dan saling membantu antara satu dengan yang lainnya, membuat kesimpulan (diskusi) serta mempresentasikan didepan kelas sebagai salah satu langkah evaluasi 
terhadap kegiatan pembelajaran yang telah dilakukan.

Tahap utama dalam pembelajaran Think Pair Share menurut Ibrahim (2000) sebagai berikut: Tahap 1. Think (berpikir) : Guru mengajukan pertanyaan atau isu yang berhubungan dengan pelajaran. Kemudian siswa diminta untuk memikirkan pertanyaan atau isu tersebut secara mandiri untuk beberapa saat.

\section{Tahap 2. Pairing} (berpasangan) : Guru meminta siswa berpasangan dengan siswa lain untuk mendiskusikan apa yang telah difikirkannya pada tahap pertama. Dalam tahap ini, setiap anggota pada kelompok membandingkan jawaban atau hasil pemikiran mereka dengan mendefinisikan jawaban yang dianggap paling benar, paling meyakinkan, atau paling unik.

Tahap 3. Share ( berbagi) : Pada tahap akhir, guru meminta kepada pasangan untuk berbagi dengan seluruh kelas tentang apa yang telah mereka bicarakan. Keterampilan berbagi dalam seluruh kelas dapat dilakukan dengan menunjuk pasangan yang secara sukarela bersedia melaporkan hasil kerja kelompoknya atau bergiliran pasangan demi pasangan hingga sekitar seperempat pasangan telah mendapat kesempatan untuk melaporkan.

Adapun kelebihan dari model pembelajaran kooperatif tipe think pair share yaitu, memungkinkan siswa untuk merumuskan dan mengajukan pertanyaan-pertanyaan mengenai materi yang diajarkan karena secara tidak langsung memperoleh contoh pertanyaan yang diajukan oleh guru, serta memperoleh kesempatan untuk memikirkan materi yang diajarkan, serta bagi guru dapat memungkinkan guru untuk lebih banyak memantau siswa dalam proses pembelajaran. Dan kelemahan dari model pembelajaran kooperatif think pair share yaitu, sangat sulit diterapkan disekolah yang rata-rata kemampuan siswanya rendah dan waktu yang terbatas, sedangkan jumlah kelompok yang terbentuk banyak.

Hasil belajar adalah kemampuan yang dihasilkan siswa setelah melewati proses belajar, yang wujudnya dapat berupa kemampuan kognitif, efektif, dan psikomotor yang disebabkan oleh pengalaman. Hasil belajar adalah pola-pola perbuatan, nilai-nilai, pengertianpengertian, sikap-sikap, apresiasi dan keterampilan. Merujuk pemikiran Gagne (Supriono, 2009). Menurut Bloom (Supriono, 2009) hasil belajar mencakup kemampuan kognitif, afektif, dan psikomotorik. Hasil belajar kemampuan-kemampuan yang dimiliki siswa setelah menerima pengalaman belajar (Sudjana, 2004).

Untuk mengetahui hasil belajar siswa diperlukan tes. Tes merupakan alat ukur yang sering digunakan untuk mengukur keberhasilan peserta didik dalam pencapaian kompetensi. Macam-macam hasil belajar dilihat dari fungsinya yaitu sebagai berikut : 1) tes seleksi, yaitu tes untuk memilih atau menyeleksi yang berhak mengikuti suatu program pendidikan, 2) tes awal (Pre-test), yaitu kegiatan menguji tingkatan pengetahuan siswa terhadap materi yang akan disampaikan, kegiatan pre test dilakukan sebelum kegiatan pengajaran diberikan. Dengan 
mengetahui kemampuan awal siswa ini, guru akan dapat menentukan cara penyampaian pelajaran yang akan ditempuhnya nanti, 3) tes akhir (Post-test), evaluasi akhir saat materi akhir saat materi yang diajarkan pada hari itu telah diberikan yang mana seorang guru memberikan post test dengan maksud apakah siswa sudah mengerti dan memahami mengenai materi yang baru saja diberikan pada hari itu.

Berdasarkan macam-macam tes hasil belajar sesuai fungsinya tersebut, maka dapat diambil tes yang berfungsi untuk melihat kemampuan individu siswa sesudah diberi perlakuan dengan model pembelajaran kooperatif tipe think pair share, disini peneliti menggunakan post-test untuk mengevaluasi siswa, (Purwanto, 2009) dan observasi untuk mengetahui berkurangnya problematika yang dihadapi siswa dalam belajar.

\section{METODE PENELITIAN}

Jenis penelitian yang digunakan dalam penelitian ini adalah penelitian kuantitatif dengan metode Quasi Eksperimen. Dimana peneliti akan bekerja dengan angkaangka sebagai perwujudan gejala yang diamati (Sugiyono 2014). Penelitian ini dilakukan di SMAN 1 Lareh Sago Halaban pada kelas $\mathrm{XI}_{1}$ dan $\mathrm{XI}_{2}$.

\section{HASIL DAN PEMBAHASAN}

Pada penelitian ini yang menjadi kelas eksperimen adalah kelas, sebelum dilakukan perlakuan pada kelas eksperimen ini terlebih dahulu dilihat hasil belajar siswa pada semester ganjil tahun ajaran
2017/2018. Setelah diketahui skor hasil belajar siswa pada mata pelajaran sejarah adalah 64,85 dengan KKM 75. Dilihat distribusi frekuensi hasil belajar siswa kelas eksperimen sebelum diterapkan model pembelajaran kooperatif tipe think pair share seperti dibawah ini :

Tabel 1 Distribusi Frekuensi Hasil Ujian Semester

\begin{tabular}{ccc}
\hline $\begin{array}{c}\text { Kelas } \\
\text { interval }\end{array}$ & Frekuensi & Persen (\%) \\
\hline $45-54$ & 3 & $14.28 \%$ \\
\hline $55-64$ & 4 & $19.04 \%$ \\
\hline $65-74$ & 9 & $42.85 \%$ \\
\hline $75-84$ & 5 & $23.80 \%$ \\
\hline Total & 21 & $100 \%$ \\
\hline
\end{tabular}

Dari tabel data diatas, dilihat hasil belajar siswa masih banyak yang masih dibawah KKM. Dapat dilihat dari kurva normal sebagai berikut :

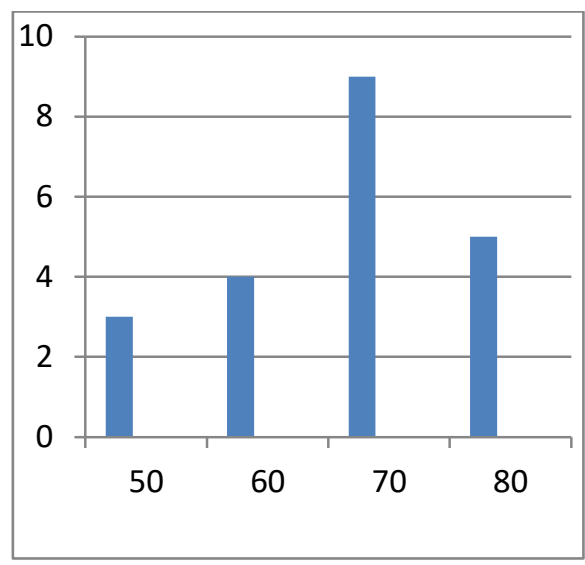

Grafik 1. Kurva Normal

Secara keseluruhan hasil belajar kelas eksperimen adalah ratarata : 76,67 simpang baku : 6,47 variansi 41,88. Untuk melihat distribusi frekuensi hasil belajar kelas eksperimen disajikan tabel dibawah ini : 


\section{Kelas Exsperimen}

Tabel 2 Distribusi Frekuensi Hasil Belajar

\begin{tabular}{ccc}
\hline Kelas Interval & Frekuensi & Persen $(\%)$ \\
\hline $60-70$ & 2 & $11,12 \%$ \\
\hline $71-80$ & 11 & $61,12 \%$ \\
\hline $81-90$ & 5 & $27,78 \%$ \\
\hline Jumlah siswa & 18 & $100 \%$ \\
\hline
\end{tabular}

Dari data pada tabel diatas, dapat dilihat bahwa setelah dilakukan perlakuan terhadap kelas eksperimen dengan penerapan model pembelajaran kooperatif think pair share dapat disimpulkan bahwa niai rata-rata siswa sudah banyak yang diatas KKM yaitu 75.

Berdasarkan data diatas, dapat dilihat histogram dan kurva normal hasil belajar kelas eksperimen total. Seperti dibawah ini :

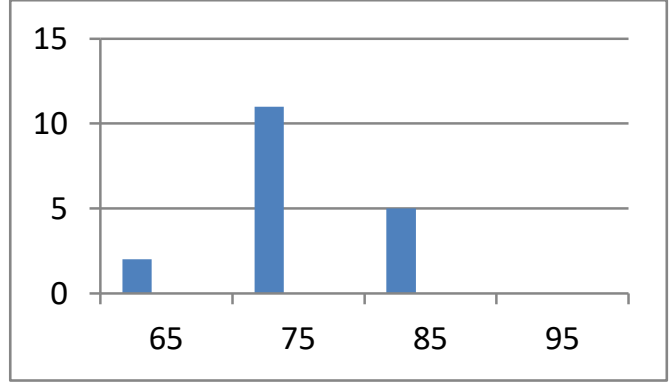

Grafik 2. Kurva Normal

\section{Kelas Kontrol}

Secara keseluruhan hasil belajar siswa $\mathrm{XI}_{1}$ yang menggunakan metode konvensional diperoleh ratarata :62 simpang baku :10,38 dan variansi : 107,80 Untuk melihat distribusi frekuensi pada kelas kontrol ini disajikan tabel VII dibawah ini :

Tabel 3Distribusi frekuensi hasil belajar siswa

\begin{tabular}{ccc}
\hline Kelas & Frekuensi & Persen (\%) \\
Interval & \\
\hline
\end{tabular}

\begin{tabular}{ccc}
\hline $40-49$ & 2 & $9,09 \%$ \\
\hline $50-59$ & 4 & $18,18 \%$ \\
\hline $60-69$ & 12 & $54,54 \%$ \\
\hline $70-79$ & 3 & $13,63 \%$ \\
\hline $80-89$ & 1 & $4,54 \%$ \\
\hline Jumlah siswa & 22 & $100 \%$ \\
\hline
\end{tabular}

Dilihat dari tabel diatas, maka hasil belajar siswa yang menggunakan metode konvensional masih banyak siswa yang nilainya masih dibawah KKM yaitu 75 . Berdasarkan tabel diatas, dapat dilihat kurva normal dari hasil belajar kelas kontrol sebagai berikut :

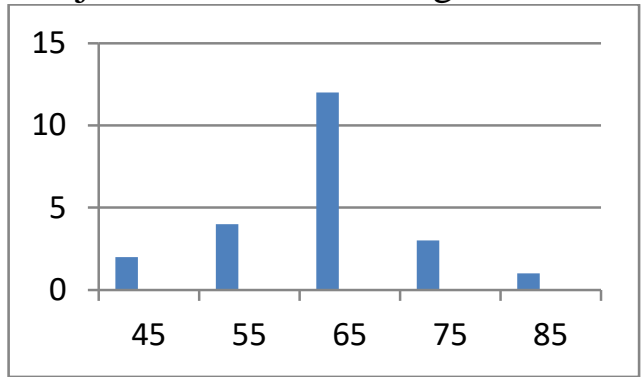

Grafik 3. Kurva Normal

Setelah dilakukan penelitian pada kedua kelas sampel maka diperoleh hasil belajar siswa kelas eksperimen dan kelas kontrol, seperti pada tabel dibawah ini ;

\section{Hasil Belajar Siswa Kelas Eksperimen dan Kelas Kontrol.}

Tabel 4 Hasil Belajar Kelas Kontrol

\begin{tabular}{cccc}
\hline Parameter & \multicolumn{2}{c}{ Kelas } & Keterangan \\
\cline { 2 - 3 } & Eksperimen & Kontrol & \\
\hline $\begin{array}{c}\text { Rata-rata } \\
\text { nilai tes } \\
\text { akhir }\end{array}$ & $\mathrm{X}_{1=} 76,67$ & $\mathrm{X}_{2=} 62$ & $\mathrm{X} 1>\mathrm{X} 2$ \\
\hline Uji & $\mathrm{L}_{\mathrm{o}=0,021}$ & $\mathrm{~L}_{\mathrm{o}=0,1042}$ & Berdistribusi \\
normal \\
Normalitas & $\mathrm{L}_{\mathrm{t}=0,173}$ & $\mathrm{~L}_{\mathrm{t}=0,173}$ & $\begin{array}{c}\text { norians } \\
\text { Uji }\end{array}$ \\
\hline Homogenitas & $\mathrm{F}_{\mathrm{h}=1,57}$ & homogen \\
\hline Uji Hipotesis & $\mathrm{F}_{\mathrm{t}=2,01}$ & $\mathrm{H} 1$ diterima \\
\hline & $\mathrm{t}_{\mathrm{h}}=18,43$ & \\
\hline
\end{tabular}


Dari data pada tabel diatas terdapat perbandingan yang signifikan dari kelas eksperimen dengan penerapan model pembelajaran kooperatif think pair share memperoleh skor hasil belajar siswa 76,67 sedangkan pada kelas kontrol yang hanya menerapkan pembelajaran konvensional memperoleh hasil skor belajar 62 . Sehingga dapat disimpulkan adanya pengaruh positif dari penerapan model pembelajaran kooperatif think pair share dibandingkan dengan pembelajaran konvensional. Untuk dapat menarik kesimpulan hasil penelitian dilakukan Uji-t. Syarat untuk menggunakan uji-t adalah data harus berdistribusi normal dan homogen. Sehingga terlebih dahulu dilakukan pengujian normalitas dan homogenitas, setelah kedua pengujian tersebut selesai dilakukan maka bisa dilakukan uji hipotesis.

\section{Uji Normalitas}

Pada ujian normalitas ini digunakan uji lifefors, berdasarkan uji normalitas kelas sampel diperoleh harga $L_{o}$ dan $L_{\mathrm{t}}$ pada taraf nyata 0,05 seperti pada tabel berikut :

Tabel 5 Hasil Uji Normalitas Kelas Eksperimen

\begin{tabular}{cccccc}
\hline Kelas & $\mathrm{N}$ & $\partial$ & $\mathrm{L}_{\mathrm{o}}$ & $\mathrm{L}_{\mathrm{t}}$ & $\begin{array}{c}\text { Kesimpu } \\
\text { lan }\end{array}$ \\
\hline $\begin{array}{c}\text { Eksperi } \\
\text { men }\end{array}$ & 1 & 0,0 & 0,0 & 0,1 & Normal \\
\hline
\end{tabular}

Berdasarkan data pada tabel diatas terlihat bahwa kelas sampel memiliki $\mathrm{L}_{\mathrm{o}}<\mathrm{L}_{\mathrm{t}}$ yang berarti antara kelas sampel berdistribusi normal.

\section{Uji Homogenitas}

Untuk mengetahui kedua kelompok data apakah memiliki varians yang homogen atau tidak, maka dilakukan uji-F. Hasil analisis homogenitas sampel dapat dilihat pada tabel dibawah ini.

Tabel 6 Hasil Uji Homogenitas Kelas Sampel

\begin{tabular}{cccccccc}
\hline Kelas & $\mathrm{N}$ & $\bar{x}$ & $\mathrm{~S}$ & $\mathrm{~S}^{2}$ & $\begin{array}{c}\mathrm{F}_{\mathrm{hi}} \\
\text { tun } \\
\mathrm{g}\end{array}$ & $\begin{array}{c}\mathrm{F}_{\mathrm{t}} \\
\text { abe } \\
\mathrm{l}\end{array}$ & $\begin{array}{c}\text { Keter } \\
\text { anga } \\
\mathrm{n}\end{array}$ \\
\hline Eksp & 2 & 76 & 6, & 41 & 1, & 1, & Hom \\
erime & 2 &, 6 & 4 &, 8 & 57 & 9 & ogen \\
$\mathrm{n}$ & & 7 & 7 & 8 & & 6 & \\
\hline
\end{tabular}

Berdasarkan tabel 6 tersebut diatas terlihat bahwa kelas sampel memiliki $\mathrm{F}_{\text {hitung }}<\mathrm{F}_{\text {tabel }}$ berarti kedua kelas sampel mempunyai varians yang homogen.

\section{Uji Hipotesis}

Setelah dilakukan uji normalitas dan homogenitas, kemudian dilakukan uji hipotesis menggunakan uji-t. Dari hasil analisis diperoleh data seperti tabel dibawah ini :

Tabel 7 Ringkasan Uji Hipotesis

\begin{tabular}{cc}
\hline Kelas Eksperimen & Kelas Kontrol \\
\hline $\mathrm{N}_{1}=18$ & $\mathrm{~N}_{2}=22$ \\
\hline $\mathrm{X}_{1}=76,67$ & $\mathrm{X}_{2}=62$ \\
\hline $\mathrm{S}_{2}=41,88$ & $\mathrm{~S}_{2}=107,80$ \\
\hline \multicolumn{2}{c}{$\mathrm{t}_{\text {hitung }}=18,43$} \\
$\mathrm{t}_{\text {tabel }}=1,73$ \\
\hline
\end{tabular}

Kesimpulan : $\mathrm{H}_{1}$ diterima karena $\mathrm{t}_{\text {hitung }}>\mathrm{t}_{\text {tabel }}$

Hasil dari uji hipotesis diatas diperoleh $\mathrm{t}_{\text {hitung }}$ : 18,43 sedangkan $t_{\text {tabel }}$ pada taraf signifikan 0,05 adalah 1,73 , berarti $t_{\text {hitung }}>t_{\text {tabel }}$. Sehingga $H_{1}$ diterima dan $\mathrm{H}_{2}$ ditolak. 
$\mathrm{H}_{\mathrm{o}}>$ Kelompok siswa yang diajarkan dengan model pembelajaran kooperatif tipe think pair share memperoleh hasil belajar yang sama dengan siswa yang diajarkan dengan metode konvensional. Maka hipotesis ini ditolak.

$\mathrm{H}_{1}$ > Kelompok siswa yang diajarkan dengan menggunakan model pembelajaran kooperatif think pair share memperoleh hasil belajar yang lebih baik dibandingkan dengan siswa yang diajar dengan metode konvensional. Maka hipotesis ini diterima.

Berdasarkan deskripsi data di atas, kelompok siswa yang mengikuti pembelajaran dengan menggunakan model pembelajaran kooperatif tipe think pair share memiliki rata-rata skor hasil belajar sejarah yang lebih tinggi dibandingkan dengan kelompok siswa yang mengikuti pembelajaran dengan menerapkan model pembelajaran konvensional. Tinjauan ini didasarkan pada ratarata skor hasil belajar sejarah siswa. Rata-rata skor hasil belajar siswa yang menerapkan model pembelajaran kooperatif think pair share adalah 76, 67 dan rata-rata skor hasil belajar siswa yang menerapkan model pemebelajaran konvensional adalah 62 .

Perbedaan hasil belajar sejarah yang signifikan antara siswa yang mengikuti pembelajaran dengan menggunakan model pembelajaran kooperatif think pair share dan siswa yang mengikuti pelajaran dengan menggunakan model pembelajaran konvensional disebabkan karena perbedaan perlakuan pada langkahlangkah pembelajaran dan penyampaian materi. Model pembelajaran think pair share lebih menekankan kepada siswa mandiri dalam belajar serta berbagi dalam berpendapat, sedangkan model pembelajaran konvensional menekankan pada hafalan. Dengan adanya perbedaan perlakuan pada langkah-langkah ini dikonstribusikan dapat berpengaruh baik dalam meningkatkan hasil belajar siswa.

Dalam proses pembelajaran menggunakan model pembelajaran Think Pair Share. Pada proses pembelajaran ini guru berperan sebagai fasilitator, guru mengajukan suatu pertanyaan atau masalah yang dikaitkan dengan pelajaran. Siswa ditugasi untuk berpikir secara secara mandiri mengenai pertanyaan atau masalah yang diajukan. Guru menugasi siswa untuk berpasangan atau berkelompok dan diskusikan mengenai apa yang telah mereka pikirkan, dan pertanyaan diajukan untuk keseluruhan kelas, lalu setiap siswa memikirkan jawabannya, kemudian siswa dibagi berpasangan dan diskusi. Pasangan ini melaporkan hasil diskusinya dan berbagi pemikiran dengan seluruh kelas.

Pada proses pembelajaran ini siswa lebih aktif dan tertarik untuk diskusi, karena yang menjelaskan teman sebaya Kelebihan model Think Pair Share ini adalah mudah dipahami oleh siswa karena siswa bisa bekerja sama dengan baik. Dan siswa lebih menguasai materi karena dijelaskan oleh teman sebayanya dengan cara masing-masing lewat presentasi kelompok. Sehingga beberapa problematika yang difokuskan dalam penulisan ini sudah teratasi, seperti siswa bosan, hasil belajar rendah,kurang berminat 
dan kurang motivasi belajar,dan lainlain yang dijelaskan dalam pendahuluan diatas.

Maka dengan penerapan model pembelajaran kooperatif think pair share dapat mendorong siswa untuk bekerja sama dalam kelompok, hal ini akan menimbulkan rasa keberanian antar individu dalam menjawab pertanyaan dari guru sehingga dapat membangun pengetahuan siswa. Dalam penerapa model pembelajaran kooperatif think pair share ini para siswa dapat bersaing dengan sehat dalam menjawab pertanyaan yang diberikan oleh guru. Dibandingkan dengan pembelajaran konvensional yang siswanya hanya mendengarkan penjelasan guru tentang materi yang diberikan, sehingga siswa akan merasa bosan dan mengantuk mendengarkan guru menerangkan materi. Karena siswa tidak diberikan suatu rangsangan yang bisa merangsang ingatan mereka dalam memahami materi pembelajaran.

Oleh sebab itu, maka pemahaman antara kedua kelas tersebut sangat berbeda, hal ini dapat dilihat dari aktifitas siswa kelas eksperimen dengan penerapan model pembelajaran kooperatif think pair share pemahaman siswa lebih baik dibandingkan siswa kelas kontrol dengan penerapan model pembelajaran konvensional yang hanya mendengarkan penjelasan guru saja sehingga siswa hanya terpaku pada guru saja.

\section{SIMPULAN}

Setelah dilihat hasil belajar dari kedua kelas sampel ini terdapat perbandingan hasil belajar antara kelas ekperimen dengan model pembelajaran kooperatif tipe think pair share lebih tinggi dibandingkan dengan kelas kontrol dengan metode konvensional yang masih rendah. Oleh sebab itu, dapat disimpulkan bahwa penerapan model pembelajaran kooperatif tipe think pair share dapat berpengaruh positif terhadap hasil belajar siswa dalam mata pelajaran sejarah. Dengan menerapkan model ini maka problematika yang dihadapi oleh baik itu guru maupun siswa itu sendiri sebagian sudah teratasi, dan sudah membawa dampak positif bagi guru dan siswa. Seperti rendahnya aktivitas belajar siswa, rendahnya hasil belajar siswa, nilai ulangan harian siswa rendah, pembelajaran di kelas masih membosankan dan monoton, guru belum melakukan variasi pembelajaran, siswa pasif selama proses pembelajaran, kurangnya penggunaan media pembelajaran, siswa sering keluar masuk, guru belum pernah menerapkan model ThinkPair Share. sebagian besar sudah teratasi.

\section{DAFTAR PUSTAKA}

Suprijono, A. (2009). Cooperatif Learning: Teori \& Aplikasi PAIKEM. Yogyakarta: Pustaka Belajar.

Ibrahim. (2000)

Model Pembelajaran Kooperatif Think Pair Share.

Purwanto. (2009). Evaluasi Hasil Belajar. Yogyakarta: Pustaka Belajar

Sudjana. (2004). Metode Statistik. Jakarta: Tarsito.

Sugiyono. (2008). Metode Penelitian Pendidikan. Bandung: Alfabeta 